showed 1040 bacteria per c.c. The sewage is passed into the Iowa River, which flows, at a minimum, about 3,250,000 gallons"per twentyfour hours and contamination by sewage is at all times serious. Where thus contaminated, its color is dark, its odor offensive and its mean content of bacteria at times as high as about 100,000 per c.c. and probably more. The outcome of litigation directed against the city by residents of the country below, along the banks of the stream, has been the determination of the city to adopt a system of purification of the sewage and it is to this end that the experts of the University were consulted.

It was promptly discovered that the glucose sewage was very different from that of the city, in respect to content of bacteria, as was to have been expected. Its bacteria ranged up to, in one case, nearly ten millions per c.c. While not unwholesome when fresh, it is subject to putrefaction of a seriously objectionable character. The packing-house sewage also contains large quantities of bacteria and has a characteristic composition. The result of intermixture: of these "various kinds of sewage is a peculiarly offensive and troublesome compound.

In seeking the best remedy for this state of affairs at Marshalltown, the data printed in the report were gathered. The work included a study of the topography of the country, of the character of the soil, the available materials for construction, of filtering and settling tanks and the costs of labor and material. It is stated that the works should be completed before November of the present year.

In the performance of the work of the consulting chemists and bacteriologists, the methods of the Massachusetts Board of Health were usually followed.

R. H. Thurston.

\section{'ARROWPOINTS, SPEARHEADS AND KNIVES OF PREHISTORIC TIMES.'}

Under the above title, Professor Thomas Wilson, Curator of the Division of Prehistoric Archæology of the U. S. National Museum, occupies pages 811 to 988 , of the Report of the Museum for 1897. Sixty-five plates and two hundred and one text figures accompany the paper. The whole is also run by the Government Printing Office, as a reprint bearing the date 1899.

Much material is brought together in this paper, besides copious references to the literature and sources of information. The chipped objects of the palæolithic period are touched upon, and sections are devoted to the origin, invention and evolution of the bow and arrow; superstitions concerning arrowpoints; flintmines and quarries of Europe and America; caches; material for points and its microscopic examination; the manufacture of points; and scrapers, grinders and straightners used in making shafts for arrows and spears. Fifty-seven pages and a proportional number of plates and figures are devoted to Mr. Wilson's classification of points for arrows and spears which is under the four main divisions, leaf-shaped, triangular, stemmed and peculiar forms. Knives and wounds made by points are also discussed. Flint mines and quarries, caches, large implements and the making of arrowpoints described by explorers and travelers are the subjects included in appendices A, B, C and D.

Some of the illustrations are familiar to readers of archæologic literature, who are glad to have them brought, together with the new illustrations, under one cover.

The manufacture of arrowpoints was seen as late as the summer of 1898 by several members of the Jesup North Pacific Expedition in the Thompson Valley, British Columbia, but in a few years it will be an industry of the past, at least in regions accessible to the body of students of archæology. Dr. Wilson has introduced a number of quaint pictures of a flint knapper engaged in chipping gun flints at Brandon, Suffolk, England.

Harlan I. Smith.

\section{DIETARY STUDIES OF UNIVERSITY BOAT CREWS.}

Professor W. O. Atwater and Mr. A. P. Bryant have prepared an interesting bulletin on the above subject, published through the Office of Experiment Stations, U. S. Department of Agriculture. Their results, together with the comparison of other dietary studies, are summarized in the following table: 